\title{
Degradation of dibutyl phthalate by Paenarthrobacter sp. Shss isolated from Saravan landfill, Hyrcanian Forests, Iran
}

\author{
S. Shariati - C. Ebenau-Jehle - A. A. Pourbabaee $\cdot$ H. A. Alikhani • \\ M. Rodriguez-Franco $\cdot$ M. Agne $\cdot$ M. Jacoby $\cdot$ R. Geiger $\cdot$ F. Shariati $\cdot$ \\ M. Boll (i)
}

Received: 20 April 2021 / Accepted: 29 October 2021 / Published online: 9 November 2021

(C) The Author(s) 2021

\begin{abstract}
Phthalic acid esters are predominantly used as plasticizers and are industrially produced on the million ton scale per year. They exhibit endocrinedisrupting, carcinogenic, teratogenic, and mutagenic effects on wildlife and humans. For this reason, biodegradation, the major process of phthalic acid ester elimination from the environment, is of global importance. Here, we studied bacterial phthalic acid ester degradation at Saravan landfill in Hyrcanian Forests, Iran, an active disposal site with 800 tons of solid waste input per day. A di- $n$-butyl phthalate degrading enrichment culture was established from
\end{abstract}

S. Shariati - C. Ebenau-Jehle - M. Agne .

M. Jacoby $\cdot$ R. Geiger $\cdot$ M. Boll $(\bowtie)$

Faculty of Biology, Microbiology, University of Freiburg, Freiburg, Germany

e-mail: matthias.boll@biologie.uni-freiburg.de

A. A. Pourbabaee $\cdot$ H. A. Alikhani

Department of Soil Science Engineering, University of

Tehran, Tehran, Iran

M. Rodriguez-Franco

Faculty of Biology, Cell Biology, University of Freiburg,

Freiburg, Germany

\section{Agne}

Spemann Graduate School of Biology and Medicine (SGBM), University of Freiburg, Freiburg, Germany

F. Shariati

Department of Environmental Science, Islamic Azad

University, Lahijan, Iran which Paenarthrobacter sp. strain Shss was isolated. This strain efficiently degraded $1 \mathrm{~g} \mathrm{~L}^{-1}$ di- $n$-butyl phthalate within $15 \mathrm{~h}$ with a doubling time of $5 \mathrm{~h}$. In addition, dimethyl phthalate, diethyl phthalate, mono butyl phthalate, and phthalic acid where degraded to $\mathrm{CO}_{2}$, whereas diethyl hexyl phthalate did not serve as a substrate. During the biodegradation of di- $n$-butyl phthalate, mono- $n$-butyl phthalate was identified in culture supernatants by ultra-performance liquid chromatography coupled to electrospray ionization quadrupole time-of-flight mass spectrometry. In vitro assays identified two cellular esterase activities that converted di- $n$-butyl phthalate to mono- $n$-butyl phthalate, and the latter to phthalic acid, respectively. Our findings identified Paenarthrobacter sp. Shss amongst the most efficient phthalic acid esters degrading bacteria known, that possibly plays an important role in di- $n$-butyl phthalate elimination at a highly phthalic acid esters contaminated landfill.

Keywords Phthalic acid ester - Ortho-phthalic acid . Microbial degradation - Bioremediation - Esterase

\section{Introduction}

Esters of ortho-phthalic acid (o-phthalic acid, 1,2benzenedicarboxylic acid) and various alcohols are termed phthalic acid esters, often simply referred to as 
phthalates. Phthalic acid esters (PAEs) are industrially produced as plasticizers to enhance the flexibility of various plastic polymer compounds. They are found in a variety of products such as paints, polishers, lubricants, adhesives, pulp and paper industries, children's toys, and cosmetic products. Introduced in the 1930s, the annual global production of PAEderived plasticizers now reaches the million ton scale accounting for $65-70 \%$ of the total plasticizer products (Baloyi et al. 2021). PAEs are non-covalently bound to plastic polymers and can easily leach from polymer matrices into the environment during manufacturing, use and disposal (Liang et al. 2008; Net et al. 2015; Gao and Wen 2016; Boll et al. 2020).

PAEs belong to a group of endocrine disrupting chemicals with numerous adverse effects on wildlife (Oehlmann et al. 2009) and human health including reproductive disorders, allergic diseases, breast cancer, testosterone level reduction, obesity, and diabetes (recently reviewed in Kahn et al. 2020). A wealth of studies have identified PAEs as contaminants in soil, surface water, sediments, seawater, municipal wastewater and landfill leachate (Liang et al. 2008; Net et al. 2015; Gao and Wen 2016).

Among PAEs, di- $n$-butyl phthalate (DBP) is one of the most extensively applied plasticizers incorporated into high-molecular weight polymers such as polyvinyl chloride (PVC), and it is categorized as a high priority chemical according to a recent risk evaluation report of the US Environmental Protection Agency under the Toxic Substances Control Act (https://www. epa.gov/assessing-and-managing-chemicals-undertsca). DBP has been found in landfill leachates, sediments, water, air, soils, plants, gas, and indoor dust (reviewed in Gao and Wen 2016; Chowdhary et al. 2018; Gao et al. 2018). Biodegradation is the major process for eliminating DBP from the environment, and the use of DBP as a carbon and energy source has been described for many aerobic bacterial strains from various ecosystems including Pseudomonas fluorescens B-1 (Xu et al. 2005), Pseudomonas sp. V21b (Kumar et al. 2017), Pseudomonas sp. YJB6 (Feng et al. 2021), Paracoccus kondratievae BJQ00001 (Xu et al. 2020), Bacillus subtilis sp. (Huang et al. 2018), B. amyloliquefaciens JR20 (Yuan et al. 2019), Achromobacter sp. (Jin et al. 2015; Benjamin et al. 2016), Rhodococcus sp. (Lu et al. 2009; Jin et al. 2010), Arthrobacter sp. $\mathrm{ZH}_{2}$ (Wang et al. 2012), Gordonia sp. (Wu et al. 2011a), Delftia sp. TBKNP-05 (Patil et al.
2006), Agrobacterium sp. (Wu et al. 2011b), Sphingobium sp. SM42 (Sungkeeree et al. 2016), S. yanoikuyae strain P4 (Mahajan et al. 2019), Acinetobacter sp. Strain LMB-5 (Fang et al. 2017), Providencia sp. 2D (Zhao et al. 2016), Methylobacillus sp. (Kumar and Maitra 2016), Ochrobactrum (Wu et al. 2010), and Comamonas sp. 51F (Kumar et al. 2017). Biodegradation of PAEs is usually initiated by the hydrolysis to phthalic acid (PA) and the respective alcohols catalyzed by intra- or extracellular esterases, often via monoalkylated intermediates (Niazi et al. 2001; Maruyama et al. 2005). In aerobic microorganisms, PA is most often converted to the central intermediate protocatechuate (3,4-dihydroxybenzoate) by two-component dioxygenases, either via 4,5-dihydro-cis-4,5dihydroxy-PA (mostly in Gram-negative bacteria) or 3,4-dihydro-cis-3,4-dihydroxy-PA intermediates (mostly in Gram-positive bacteria) (Gao and Wen 2016; Boll et al. 2020) (Fig. 1).

The Hyrcanian Forests stretch $850 \mathrm{~km}$ along the southern coast of the Caspian Sea with a history dating back 25-50 million years. In 2019, they have been registered as a UNESCO World Heritage Site with a remarkable biodiversity (https://whc.unesco.org/en/ list/1584/). The Saravan landfill is located inside Hyrcanian Forests $20 \mathrm{~km}$ outside of Rasht, Iran. With 800 tons of solid waste input per day, it severely endangers the ecosystem. Approximately $7 \mathrm{~L} \mathrm{~s}^{-1}$ of leachate are discharged from the Saravan landfill site to the soil, river, and groundwater. This leachate contains a considerable amount of heavy metals and numerous toxic organic compounds that seep into the international Anzali wetland near the Caspian Sea causing severe environmental problems. Plastics are second most abundant waste behind food waste in terms of incoming solid material to Saravan landfill (Shariatmadari et al. 2018; Karimpour-Fard 2019).

Here, we have evaluated bacterial degradation of PAE-derived plasticizers at the Saravan landfill. For this purpose, we established DBP-degrading enrichment cultures from which a Paenarthrobacter sp. was isolated with the capability of using many PAEs and $o$ phthalate as a sole source of energy and carbon. The study is accompanied by in vitro esterase assays and mass spectrometry-based analyses of degradation intermediates. 
Fig. 1 Degradation pathways of PAEs in aerobic bacteria. $R_{1}$ and

$\mathrm{R}_{2}=$ variable alkyl chains including methyl, ethyl, butyl, isobutyl, benzyl and 2-ethylhexyl functionalities. The first and second hydrolysis of the ester bonds may occur simultaneously without the formation of a monoalkyl phthalate intermediate<smiles>[R]OC(=O)c1ccccc1C(=O)O[R]</smiles><smiles>[R]OCC1CC1CCO</smiles><smiles>[R]OC(=O)c1ccccc1C(=O)[O-]</smiles><smiles>[R20]OC1CC1C(C)CO</smiles>

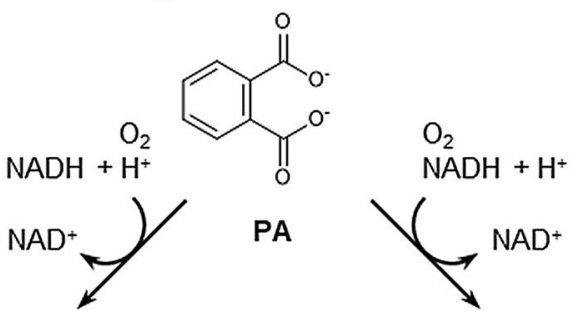<smiles>O=C([O-])C1=C[C@H](O)[C@@H](O)C=C1C(=O)[O-]</smiles><smiles>O=C([O-])C1=C(C(=O)[O-])C(O)[C@H](O)C=C1</smiles>

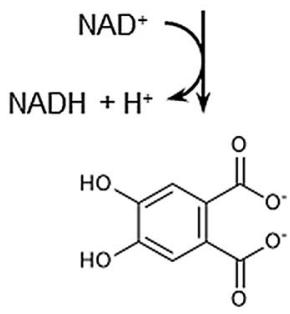

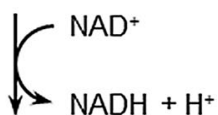<smiles>O=C([O-])c1ccc(O)c(O)c1C(=O)[O-]</smiles><smiles>CC1CCC1C(=O)O</smiles><smiles>CC1CC1[CH+]CC(=O)[O+]</smiles><smiles>O=C([O-])c1ccc(O)c(O)c1</smiles>

$\mathrm{CO}_{2}$

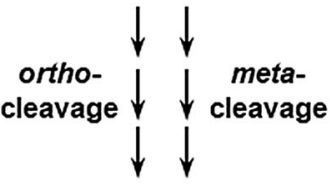

TCA cycle 


\section{Material and methods}

Chemicals

Monobutyl phthalate (MBP, 99\% purity), di-n-butyl phthalate (DBP, 99\%), diethylhexyl phthalate (DEHP, 99.5\%), diethyl phthalate (DEP, 99\%), dimethyl phthalate (DMP, 99\%), phthalic acid (PA, > 99.5\%), 2-ethyl-1-hexanol (99.6\%), terephthalic acid (98\%), and isophthalic acid (99\%) were purchased from Sigma Aldrich Chemie GmbH (Hamburg, Germany). Acetonitrile, ethyl acetate, hexane, and formic acid were of HPLC grade and purchased from Carl Roth (Karlsruhe, Germany).

Study area and sampling

Saravan landfill is located in the area of Rasht city, between the transit road of Rasht-Tehran and Siahrood River at an altitude of 50-250 m above sea level. More than 700 tons of waste are buried daily in this area in an unprincipled approach for 30 years. The vast and continuous flow of waste dumped at the site has led to an accumulation of waste up to $70 \mathrm{~m}$ (Karimpour-Fard 2019). Saravan waste leachate enters Anzali wetland and the Caspian Sea through Zarjub, Sefidrood, and Pirbazar rivers. Other environmental hazards include leachate penetration into the lower layers of the soil and groundwater contamination, atmospheric gas emissions, native and indigenous animals feeding on the wastes, and damages to vegetation and wildlife (Shariatmadari et al. 2018). The sampling was performed at a depth of $0-10 \mathrm{~cm}$ in three downstream areas of the landfill site (leachate passing site, longitude 378,296, latitude 4,105,555). In addition, samples were taken from an downstream area of the landfill site, which was not exposed to the leachate pollution (longitude 378,243 , latitude $4,105,915$ ).

Measurement of some physical and chemical properties and PAEs of soil

Soil samples were air-dried, passed through a $2 \mathrm{~mm}$ sieve, and then dried in an oven at $105{ }^{\circ} \mathrm{C}$ for $10 \mathrm{~h}$. Soil organic matter was measured by the WalkleyBlack titration method. Electrical conductivity and the soil $\mathrm{pH}$ were measured in a 1:1 (soil: water) extract by an EC meter (JENWAY 4320), and $\mathrm{pH}$ meter (UNICAM 9455) respectively. For measurement of
PAEs in soil samples, dioctyl adipate (DOA) as an internal standard was added to $1 \mathrm{~g}$ of the freeze-dried soil sample and $10 \mathrm{~mL}$ methanol was added. The mixture was vortexed (5 min), sonicated (30 min) and centrifuged (5 min at $3500 \mathrm{rpm}$ ). Subsequently, $5 \mathrm{~mL}$ of the upper phase was removed, followed by addition of $1 \mathrm{~mL}$ hexane after which the mixture was vortexed ( $2 \mathrm{~min}$ ). Finally, $1 \mu \mathrm{L}$ of the extracted hexane phase was injected into a gas chromatograph coupled to a triple quadrupole mass spectrometer detector (GCMS, 7890A, Agilent) for PAEs determination. Chromatographic determination of PAEs was performed using a DB-5 ms column (J\&W Scientific). The initial temperature of the column was $80{ }^{\circ} \mathrm{C}(2 \mathrm{~min})$, then increased to $285{ }^{\circ} \mathrm{C}$ with $7{ }^{\circ} \mathrm{C} / \mathrm{min}$ and was kept at $285^{\circ} \mathrm{C}$ for $7 \mathrm{~min}$. Helium gas was used as a carrier gas and splitless mode was used for sample injection. The GC injector and the MSD transfer line temperatures were set to $290{ }^{\circ} \mathrm{C}$, and the ion source and quadrupole analyzer temperatures were adjusted to 230 and $150{ }^{\circ} \mathrm{C}$, respectively.

Enrichment of a microbial consortium degrading PAEs

The enrichment procedure was adapted from Jin et al. (2015) with slight modifications. A mineral salt medium (MSM) consisting of $\mathrm{CaCl}_{2} 0.01 \mathrm{~g} \mathrm{~L}^{-1}$, $\mathrm{MgSO}_{4} 0.1 \mathrm{~g} \mathrm{~L}^{-1}, \mathrm{KH}_{2} \mathrm{PO}_{4} 4.5 \mathrm{~g} \mathrm{~L}^{-1},\left(\mathrm{NH}_{4}\right)_{2} \mathrm{SO}_{4} 1 \mathrm{~g}$ $\mathrm{L}^{-1}, \mathrm{NaCl} 1 \mathrm{~g} \mathrm{~L}^{-1}, \mathrm{~K}_{2} \mathrm{HPO}_{4} 5.8 \mathrm{~g} \mathrm{~L}^{-1}$, and SL10 trace elements, $\mathrm{pH} 7$, was used for enrichment and isolation. Contaminated soil (5 g) was mixed with $50 \mathrm{~mL}$ of sterile MSM in an Erlenmeyer flask with $100 \mathrm{mg} \mathrm{L}^{-1}$ of DEHP, DBP, DEP, DMP, respectively. The medium was incubated at $30{ }^{\circ} \mathrm{C}$ and $180 \mathrm{rpm}$ for 7 days. $1 \mathrm{~mL}$ of the suspension was added to a fresh MSM containing $200 \mathrm{mg} \mathrm{L}^{-1}$ of PAEs and was incubated again for 1 week. Dependent on bacterial growth, this process was continued by increasing the amount of PAEs stepwise up to $1000 \mathrm{mg} \mathrm{L}^{-1}$ in the media. Four and eight weeks after incubation, the capability of the consortium to remove PAEs was evaluated via GC-MS analysis as described above and compared with controls without soil addition. 
Isolation and identification of bacterial DBP degraders

A DBP degrading bacterium was isolated on solid medium using MSM agar supplemented with $5 \mu \mathrm{L}$ DBP (distributed on the agar surface); as a control, plates without a carbon source were prepared. The $16 \mathrm{~S}$ rRNA gene was directly amplified from bacterial suspension using the bacterial primers $27 \mathrm{~F}\left(5^{\prime}-\right.$ AGAGTTTGATCCTGGCTCAG- $\left.3^{\prime}\right)$ and 1492R ( $5^{\prime}$ GGTTACCTTGTTACGACTT-3'). The $50 \mu \mathrm{L}$ PCR reaction contained $25 \mu \mathrm{L}$ Red Tag polymerase (Genaxxon bioscience, Ulm, Germany), $2.5 \mu \mathrm{L}$ forward primer $(10 \mu \mathrm{M}$ stock solution), $2.5 \mu \mathrm{L}$ reverse primers (10 $\mu \mathrm{M}$ stock solution), $20 \mu \mathrm{L}$ sterile distilled water and a small amount of the pure colony. PCR mixture was applied to a temperature cycler (Flex cycler, Analytik Jena, Jena, Germany). The program used for PCR consisted of an initial denaturation step at $95{ }^{\circ} \mathrm{C}$ for $5 \mathrm{~min}$, followed by 34 cycles at $95{ }^{\circ} \mathrm{C}$ for $30 \mathrm{~s}$, $55{ }^{\circ} \mathrm{C}$ for $30 \mathrm{~s}$, and $72{ }^{\circ} \mathrm{C}$ for $90 \mathrm{~s}$, plus a final step at $72{ }^{\circ} \mathrm{C}$ for $5 \mathrm{~min}$. The PCR product was evaluated by $1 \%$ agarose gel electrophoresis, quantified by a NanoDrop (PeqLab, Erlangen, Germany), and sequenced by Sanger sequencing (Eurofins Genomics Germany, Ebersberg, Germany).

\section{Transmission electron microscopy}

Exponentially grown cells with $1000 \mathrm{mg} \mathrm{L}^{-1} \mathrm{DBP}$ as carbon and energy source were adsorbed to glowdischarged Formvar-carbon-coated grids by placing $10 \mu \mathrm{L}$ of the cell-suspension on the grid for $5 \mathrm{~min}$. Samples were washed three times by touching the surface of the grid with drops of distilled $\mathrm{H}_{2} \mathrm{O}$, and negatively stained for $30 \mathrm{~s}$ with $2 \%$ (wt/vol)uranyl acetate. Cells were imaged at $100 \mathrm{keV}$ using a Hitachi HT7800 TEM coupled to a Xarosa Emsis camera.

Substrate utilization assays

DBP, DEHP, DEP, DMP, MBP (200 mg L $\left.{ }^{-1}\right)$, 2-ethyl hexanol $\left(100 \mathrm{mg} \mathrm{L}^{-1}\right)$, isophthalic acid $(5 \mathrm{mM})$, terephthalic acid $(5 \mathrm{mM})$, and ortho-phthalic acid $(10 \mathrm{mM})$ were used as sole carbon sources to test the capability of strain Shss to grow with these compounds in the same mineral salt medium as described above for the enrichment of the culture. The growth of strain Shss was measured at a wavelength of $578 \mathrm{~nm}$ by a UV-Ultrospec 3000 pro spectrophotometer (Pharmacia, Uppsala, Sweden).

Biodegradation assay of DBP by strain Shss and identification of downstream products

For measuring the biodegradation of DBP by strain Shss, cells from an exponentially growing pre-culture were added to $10 \mathrm{~mL}$ medium containing $1000 \mathrm{mg}$ (approximately $3.7 \mathrm{mM}$ ) DBP. The DBP had been added to the mineral salt medium described from a 100-fold stock solution in methanol. In control experiments, it was verified that methanol did not serve as carbon source. The cultures were incubated at $30{ }^{\circ} \mathrm{C}$ and $150 \mathrm{rpm}$. For analysis of metabolites, the entire culture was first acidified with $1 \mathrm{~mL} 1 \mathrm{M} \mathrm{HCl}$ followed by the extraction with an equal volume of ethyl acetate. The ethyl acetate phase was then diluted 1:4 (v/v) with methanol. Detection and identification of DBP and metabolites of its degradation were performed with an Acquity ultra performance liquid chromatography (UPLC $\AA$, Waters, MA) system coupled to a photodiode array detector. The chromatographic separation was performed using a $\mathrm{BEH}-\mathrm{C}_{18}$ column $(2.1 \times 100 \mathrm{~mm}, 1.7 \mu \mathrm{m}$; Waters, MA, USA $)$ at $30{ }^{\circ} \mathrm{C}$ and an acetonitrile (solvent $\mathrm{A}$ ) and $10 \mathrm{mM}$ ammonium formate $\mathrm{pH} 3$ (solvent $\mathrm{B}$ ) gradient at a flow rate of $0.3 \mathrm{~mL} \mathrm{~min}{ }^{-1}$. The separation was accomplished by increasing the amount of solvent $\mathrm{A}$ from 5 to $100 \%$ within 4 min. $\mathrm{DBP}, \mathrm{MBP}$ and $\mathrm{PA}$ were identified by their UV absorbance at $275 \mathrm{~nm}$ at a retention time of 5.3, 4.2, and 3.6 min, respectively. Chromatograms were analyzed using the Empower 3 (Waters, MA, USA) software. The residual concentrations of DBP and its intermediates in the liquid culture were calculated by extrapolating the peak area with standard curves.

\section{Identification of MBP by UPLC-ESI-QTOF-MS/ MS}

To confirm the nature of the intermediate identified via UPLC analysis, samples were analyzed after UPLC separation and electrospray ionization (ESI) by a quadruple time of flight MS device (ESI-Q-TOF-MS, Synapt G2-Si, Waters). Target compounds were separated using a $\mathrm{BEH} \mathrm{C}_{18}$ column as described above. MS/MS analysis was performed at full scan mode in the $\mathrm{m} / \mathrm{z}$ range of $50-1200$ using an 
electrospray ionization (ESI) in negative mode with a capillary voltage of $1.5 \mathrm{kV}$, a source temperature of $120{ }^{\circ} \mathrm{C}$, desolvation gas temperature of $500{ }^{\circ} \mathrm{C}$, a gas flow of $800 \mathrm{~L} \mathrm{~h}^{-1} \mathrm{~N}_{2}$, and a cone gas flow of $50 \mathrm{~L} \mathrm{~h}^{-1}$ $\mathrm{N}_{2}$. Collision induced dissociation of precursor ions was performed by ramping the collision energy from 10 to $40 \mathrm{~V}$. Ions with an $\mathrm{m} / \mathrm{z}$ of $221.08( \pm 0.01)$ and $165.02( \pm 0.01)$ were monitored to identify MBP and PA, respectively. The data analysis was performed using Mass Lynx V4.1. The intermediates were identified by the mass pattern of each compound at the retention time of authentic standards.

Growth with $o$-phthalic acid

To investigate the biodegradation of $o$-phthalic acid (PA) by strain Shss, $0.5 \mathrm{~mL}$ of an exponentially growing Shss pre-culture $\left(\mathrm{OD}_{578}=0.5\right)$ was inoculated in MSM supplemented with $12 \mathrm{mM}$ PA. The culture was incubated at $30{ }^{\circ} \mathrm{C}$ and $180 \mathrm{rpm}$ for 2 days. The growth of strain Shss was monitored at $\mathrm{OD}_{578}$. After acidification of the culture with $1 \mathrm{M} \mathrm{HCl}$ to $\mathrm{pH} \mathrm{2,} \mathrm{the} \mathrm{PA} \mathrm{concentration} \mathrm{was} \mathrm{determined}$ photometrically at $276 \mathrm{~nm}\left(\varepsilon=1200 \mathrm{~mol}^{-1} \mathrm{~cm}^{-1}\right)$ (Ebenau-Jehle et al. 2017).

In vitro DBP and MBP esterase assays

Cells were grown in 2-L-Erlenmeyer flasks containing $800 \mathrm{~mL}$ mineral salt medium media described above with $3.7 \mathrm{mM}$ DBP $\left(30{ }^{\circ} \mathrm{C}\right)$ while shaking at $150 \mathrm{rpm}$. For measuring intracellular esterase activities, cells at $\mathrm{OD}_{578 \mathrm{~nm}} 0.5$ were centrifuged (20 min, $6000 \mathrm{rpm}$, PTI F7S), washed four times with media without substrate (20 min, $6000 \mathrm{rpm}$, Hermle A8.24) and suspended in $3 \mathrm{~mL}$ of the remaining media. DNase was added before passing the suspension twice through a French pressure cell at $5.4 \mathrm{MPa}$. The crude extract was centrifuged at $100,000 \times g$ for $1 \mathrm{~h}$. The resulting supernatant was used for the enzyme assays; supernatant heated for $15 \mathrm{~min}$ at $95{ }^{\circ} \mathrm{C}$ served as a negative control. For testing possible extracellular esterase activities, culture supernatant was 100 -fold concentrated by ultrafiltration $(10 \mathrm{kDa}$, Amicon cell, model 8200 , Amicon) prior to use in assays.

Assays for analyzing intracellular esterase activities contained $930 \mu \mathrm{L}$ medium, $10 \mu \mathrm{L} 2 \mathrm{M}$ Tris/HCl pH 8.8 (resulting in final $\mathrm{pH} 7.2$ ), and $50 \mu \mathrm{L}$ cell extract. In assays for extracellular esterase activities,
$990 \mu \mathrm{L}$ the 100 -fold concentrated culture medium was used directly. Both assays were started by the addition of $10 \mu \mathrm{L}$ of a $100 \mathrm{mM}$ DBP stock solution in methanol. Samples of $100 \mu \mathrm{L}$ were taken at different time points by adding $400 \mu \mathrm{L} 0.1 \%$ formic acid in methanol. After centrifugation (20 min, 14,000 rpm), samples were analyzed by UPLC as described above, but the solvent system was modified to 0.1 formic acid in methanol (solvent $\mathrm{A}$ ) and $0.1 \%$ formic acid in water (solvent B). DBP, MBP and PA were identified at $275 \mathrm{~nm}$ at a retention time 5.6, 4.9 and $4.0 \mathrm{~min}$ respectively. Specific activities were defined as nmol DBP or MBP consumed per minute per mg protein in the extract/supernatant Protein concentration was determined by the Bradford method.

\section{Results and discussion}

Physical and chemical properties and PAEs concentration of soil from Saravan landfill

Table 1 shows the concentrations of various PAEs and data from physicochemical analyses in soil samples taken downstream and upstream of the leachate of the Saravan landfill. The 3.4-fold higher electric conductivity of the downstream samples is assigned to leachate components. In accordance with previous studies from other sites (Net et al. 2015; Gao and Wen 2016; Gao et al. 2018), DEHP and DBP were the major PAE components found in the soil samples from Saravan landfill. They were 4.5- and 10-fold above the ecological risk limit (ERL) values of DEHP $\left(1 \mathrm{mg} \mathrm{kg}^{-1}\right)$ and DBP $\left(0.7 \mathrm{mg} \mathrm{kg}^{-1}\right)$, respectively (Net et al. 2015). The fivefold higher concentration of DEHP vs DBP is assigned to its generally lower biodegradation rates resulting in a higher persistence at the landfill (Net et al. 2015).

Establishment of a PAE-degrading bacterial enrichment culture

For establishing a PAE degrading bacterial enrichment culture, the soil exposed to leachate was incubated with a mixture of PAEs including DMP, DEP, DBP, and DEHP. For the adaptation of the culture, the concentration of the individual PAEs was stepwise increased from 100 to $1000 \mathrm{mg} \mathrm{L}^{-1}$. Growth was determined by $\mathrm{OD}_{578}$ measurements and the 
Table 1 Physicochemical properties and PAE concentrations of samples taken from Saravan landfill

\begin{tabular}{|c|c|c|}
\hline Property & Exposed to leachate & Not exposed to leachate \\
\hline $\mathrm{pH}$ & 8.2 & 7.9 \\
\hline Electric conductivity $\left(\mathrm{dS} \mathrm{m}^{-1}\right)$ & 0.825 & 0.242 \\
\hline Clay/silt/sand (\%) & $28 / 28 / 44$ & $41 / 38 / 21$ \\
\hline Organic matter $(\%)$ & 1.64 & 2.31 \\
\hline Dimethylphthalate $\left(\mathrm{mg} \mathrm{kg}^{-1}\right)$ & $<0.01$ & $<0.01$ \\
\hline Diethylphthalate $\left(\mathrm{mg} \mathrm{kg}^{-1}\right)$ & $<0.01$ & $<0.01$ \\
\hline Benzyl butyl phthalate $\left(\mathrm{mg} \mathrm{kg}^{-1}\right)$ & 0.447 & 0.462 \\
\hline Di- $n$-butylphthalate $\left(\mathrm{mg} \mathrm{kg}^{-1}\right)$ & 0.765 & 0.672 \\
\hline Diisobutylphthalate $\left(\mathrm{mg} \mathrm{kg}^{-1}\right)$ & 0.082 & 0.065 \\
\hline Diethylhexyl phthalate $\left(\mathrm{mg} \mathrm{kg}^{-1}\right)$ & 4.51 & 0.404 \\
\hline Total PAE (mg kg $\left.{ }^{-1}\right)$ & 5.804 & 1.603 \\
\hline
\end{tabular}

consumption of individual PAEs was monitored by GC-MS analyses. When incubated with $400 \mathrm{mg} \mathrm{L}^{-1}$ PAEs, DMP, DEP, and DBP were degraded almost completely within 4 weeks, whereas $45 \%$ of the added DEHP remained (Fig. 2a). The consortium degraded $98.8 \%, 96.4 \%, 84.7 \%$, and $38.3 \%$ of $1000 \mathrm{mg} \mathrm{L}^{-1}$ DMP, DEP, DBP, and DEHP, respectively (Fig. 2b). Degradation was accompanied by an increase of $\mathrm{OD}_{578}$ between 0.8 and 1.25. In a control without $\mathrm{PAE}$ addition, $\mathrm{OD}_{578}$ remained at 0.07 and 0.075 , respectively, indicating that the increase of $\mathrm{OD}_{578}$ correlates with PAE consumption. The observation of the lower degradation rate of DEHP vs PAEs with smaller alkyl chains has frequently been observed. The preferred degradation of DMP, DEP, and DBP vs DEHP reflects their low concentrations in the landfill leachate. In contrast, the residual high concentration of
DEHP (4.51 mg kg ${ }^{-1}$ ) is assigned to the lower biodegradation rate of this PAE.

Isolation of PAE-degrading bacterial strains

From the PAE-degrading enrichment culture established from Saravan landfill leachate, attempts to isolate bacterial strains using PAEs as carbon and energy source under aerobic conditions were performed using an agar-based solid medium. After 2 months of incubation, the formation of orange colonies was observed in a mineral salt medium containing agar and DBP $(5 \mu \mathrm{L}$ distributed on the agar surface) as only carbon and energy source; similar colonies were formed in LB medium (Fig. 3a). The cells of the strain referred to as strain Shss were rodshaped/coccoidal with an average diameter $\times$ length
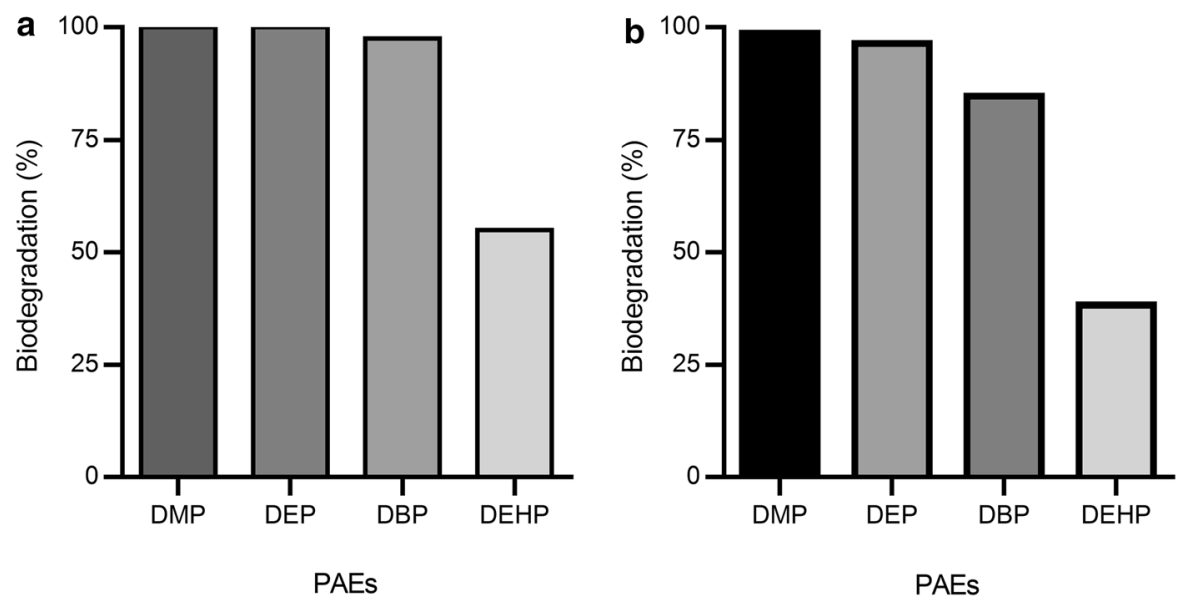

Fig. 2 Biodegradation of PAEs by the enrichment culture SA1 established from Saravan landfill leachate. a After 4 (400 mg L $\mathrm{L}^{-1}$ substrate) and $\mathbf{b} 8$ weeks (1000 $\mathrm{mg} \mathrm{L}^{-1}$ substrate) of cultivation. $100 \%$ refers to the complete removal of PAEs 


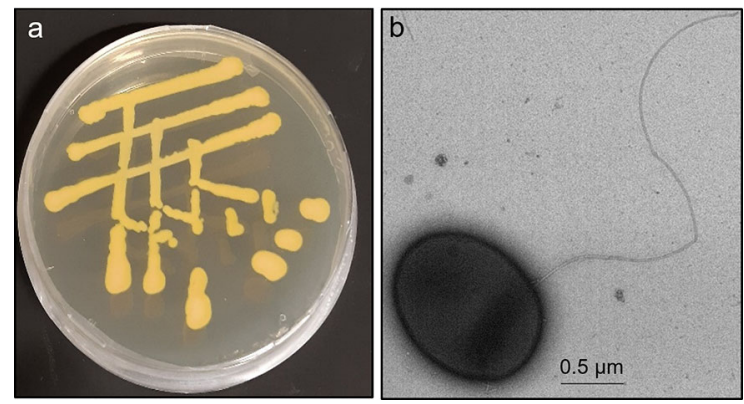

Fig. 3 Paenarthrobacter sp. strain Shss isolated in this work. a Growth on LB-agar. b Transmission electron microscopy image of a exponentially grown cell in liquid medium with $1 \mathrm{~g}$ $\mathrm{L}^{-1} \mathrm{DBP}$, contrasted by negative staining

$\approx 0.7 \mu \mathrm{m} \times 1.2 \mu \mathrm{m}$ (Fig. 3b). The strain was Grampositive, not spore-producing, catalase-positive, motile, and contained a single flagellum (Fig. 3b). The 16S rRNA gene was amplified by colony PCR. BLAST analysis of the sequence obtained (1068 bp) revealed $99.44 \%$ identity to Paenarthrobacter ureafaciens strain NC (DSM 20126). The partial 16S rRNA gene sequence of Paenarthrobacter sp. strain Shss was registered in NCBI GenBank with the accession number MN310736.

Paenarthrobacter strain Shss utilized DBP, MBP, DEP, DMP (200 $\left.\mathrm{mg} \mathrm{L}^{-1}\right)$, and PA (5 mM) as the sole source of carbon and, together with $\mathrm{O}_{2}$, as an energy source $\left(\mathrm{OD}_{578}\right.$ reached were $\geq 0.3$ during growth with each substrate). It did not utilize DEHP, MEHP (200 mg L $\mathrm{m}^{-1}$, each), 2-ethyl hexanol (200 $\left.\mathrm{mg} \mathrm{L}^{-1}\right)$, terephthalic and isophthalic acid (5 $\mathrm{mM}$ each).

\section{Analysis of culture intermediates during DBP} degradation by Paenarthrobacter strain Shss

The growth of Paenarthrobacter strain Shss with DBP and the formation of intermediates in the culture medium were investigated. For this purpose, the culture supernatants were analyzed by UPLC coupled to photodiode array detection at different $\mathrm{OD}_{587}$ values reached. DBP $\left(1000 \mathrm{mg} \mathrm{L^{-1 }}\right)$ was almost completely degraded within $15 \mathrm{~h}$ coupled to an increase of $\mathrm{OD}_{578}$ to around 1.0 (Fig. 4a). While DBP continuously decreased in the course of the growth experiment, a product increased within the first $10 \mathrm{~h}$ of incubation. In the following $5 \mathrm{~h}$, it was completely consumed indicating that it represents a transiently accumulating intermediate during DBP degradation. The intermediate was subjected to UPLC analysis coupled to ESI-QTOF-MS detection. It coeluted with an authentic MBP standard, and the monitored ions $\mathrm{m} / \mathrm{z} 221.08 \pm 0.01$ and $165.02 \pm 0.01$ (negative mode) were fitted to those of the standard and the calculated mass (Fig. 4c).

The results obtained suggest that DBP was degraded via MBP to one PA and two molecules $n$ butanol. As PA was not detected at significant concentrations in the medium, it was suggested that it was readily further degraded by intracellular enzymes. To confirm this assumption, growth of Paenarthrobacter strain Shss with $2000 \mathrm{mg} \mathrm{L}^{-1} \mathrm{PA}$ as only carbon and energy source was investigated. Indeed, it readily converted PA under aerobic conditions with approximately $1000 \mathrm{mg} \mathrm{L}^{-1}$ of PA being consumed within $15 \mathrm{~h}$ (Fig. 4b). Thus, DBP and PA are apparently degraded at similar rates suggesting that hydrolysis of DBP to PA via MPB is not rate limiting during complete DBP degradation.

The complete degradation of $1000 \mathrm{mg} \mathrm{L}^{-1} \mathrm{DBP}$ within $15 \mathrm{~h}$ by strain Paenarthrobacter strain Shss was combined with a growth to $\mathrm{OD}_{578} \approx 1.0$. The very low doubling time perfectly correlated with the halflife of DBC (both $5 \mathrm{~h}$ ). These values place Paenarthrobacter strain Shss among the most efficient DBP degrading microorganisms known to date. In Table 2, a compilation of reports on microbial DBP degradation at high concentrations (threshold set to $\geq 400 \mathrm{mg} \mathrm{L}^{-1}$ ) is presented; in addition, studies that reported on the degradation on DBP concentrations above $1000 \mathrm{mg} \mathrm{L}^{-1}$ are further discussed below. Notably, a direct comparison of degradation rates determined in individual studies has to be taken cautiously, as the studies have often been conducted under different conditions.

In Achromrobacter denitrificans SPI, the complete consumption of $2780 \mathrm{mg} \mathrm{L}^{-1}(10 \mathrm{mM})$ within $24 \mathrm{~h}$ appears to be the highest rate reported so far, however, no quantitative correlation between biomass production and DBP consumption was presented (Benjamin et al. 2016). The degradation of $1000 \mathrm{mg} \mathrm{DBP} \mathrm{L}^{-1}$ in $12 \mathrm{~h}$ in S. yanoikuyae strain $\mathrm{P} 4$ was accompanied by growth to $\mathrm{OD}_{600}=1.4$ (Mahajan et al. 2019), which is in the range of the values obtained with Paenarthrobacter strain Shss. In Rhodococcus sp. JDC11 , the complete degradation of $1000 \mathrm{mg} \mathrm{L}^{-1}$ was achieved within $24 \mathrm{~h}$, however the biomass formed 

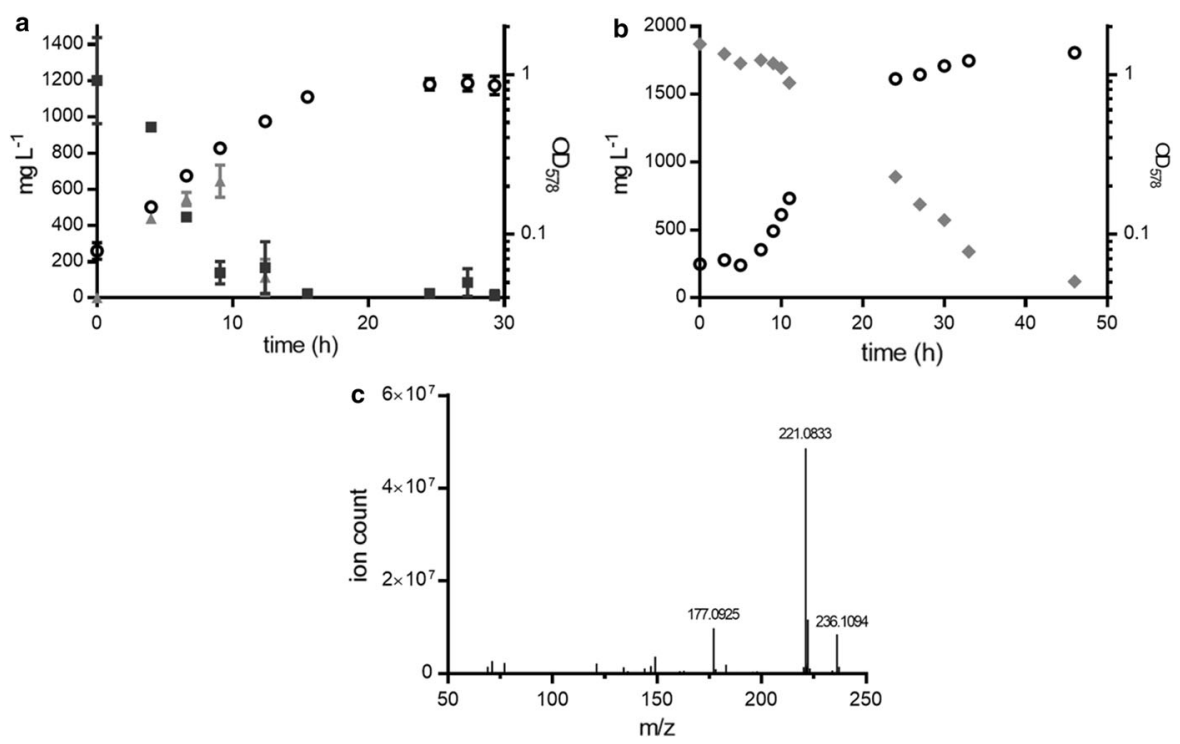

Fig. 4 Growth of Paenarthrobacter strain Shss with DBP and PA. a Growth curve with DBP as determined by $0 \mathrm{OD}_{578}$, the consumption of DBP, and the transient formation of $\boldsymbol{\Delta} \mathrm{MBP}$.

during this process was not reported (Jin et al. 2010). Delftia sp. TBKNP-05 completely degraded $2780 \mathrm{mg}$ $\mathrm{L}^{-1}$ in $120 \mathrm{~h}$ and reached an $\mathrm{OD}_{660}$ of 1.4 (Patil et al. 2006), whereas Methylobacillus sp. V29b degraded $1400 \mathrm{mg}$ in $192 \mathrm{~h}$, thereby only growing to $\mathrm{OD}_{600-}$ $=0.3$ (Kumar and Maitra 2016). In Pseudomonas sp. YJB6, the degradation of $1600 \mathrm{mg} \mathrm{L}^{-1} \mathrm{DBP}$ was accompanied with an increase of $\mathrm{OD}_{600}$ around 1.0 (Feng et al., 2021). In contrast, only very low $\mathrm{OD}_{600}$ values of around 0.16 were reported in Pseudomonas strain V21b and Comamonas sp. 51F during the $192 \mathrm{~h}$ degradation of $1200 \mathrm{mg} \mathrm{L}^{-1}$ DBP and $900 \mathrm{mg} \mathrm{L}^{-1}$, respectively (Kumar et al. 2017). These examples reflect that the correlation of biomass formation and DBP degradation varies strongly in these studies, indicating either largely differing DBP assimilation capacities of individual strains and/or technical differences in analyzing growth and DBP biodegradation. In summary, among the strains reported to degrade DBP at concentrations higher than $1000 \mathrm{mg}$ $\mathrm{L}^{-1}$, Paenarthrobacter strain Shss appears to be highly efficient in terms of degradation rate and assimilation into biomass. b Growth curve with PA as determined by $\mathrm{OD}_{578}$ measurements and the consumption of PA. c Ion chromatogram of MBP as determined by UPLC-ESI-QTOF-MS

Cellular esterases are involved in DBP degradation in Paenarthrobacter sp. strain Shss

UPLC-based analyses of culture supernatants during the degradation of DBP by Paenarthrobacter strain Shss suggested MBP as an intermediate during DBP degradation. To determine whether this accumulation was due to extracellular or cellular esterases, cells were grown on the 800 -mL-scale to $\mathrm{OD}_{578 \mathrm{~nm}} \approx 0.5$. Samples from these cultures were separated in cellfree culture supernatants and entire cells by centrifugation. Both fractions were analyzed by UPLC for MBP and MBP consumption and PA formation. Using 100-fold concentrated culture supernatants in the assays, virtually neither DBP nor MBP esterase activities were monitored. In contrast, using cell extracts from washed cells, the time-dependent consumption of DBP and the formation of MBP was monitored at a specific rate of $104 \mathrm{nmol}$ DBP consumed $\min ^{-1} \mathrm{mg}$ (protein) ${ }^{-1}$ (Fig. 5a). In heattreated controls, no DBP esterase activity was observed. When MBP replaced DBP as substrate in assays with cell extracts, the ready conversion to PA was observed at a specific rate of $295 \mathrm{nmol}$ MBP consumed $\min ^{-1} \mathrm{mg}$ (protein) ${ }^{-1}$ (Fig. 5b). These results indicate that both, DBP and MBP hydrolysis are catalyzed by cellular esterases. The transient 
Table 2 Bacterial strains reported to degrade DBP at concentrations $\geq 400 \mathrm{mg} \mathrm{mL}^{-1}$

\begin{tabular}{lll}
\hline Strain & DBP degradation capability & References \\
\hline Achromobacter denitrificans SP I & $2780 \mathrm{mg} \mathrm{L}^{-1}$ in $24 \mathrm{~h}$ & (Benjamin et al. 2016) \\
Paenarthrobacter strain Shss & $1000 \mathrm{mg} \mathrm{L}^{-1}$ in $15 \mathrm{~h}$ & This work \\
Sphingobium yanoikuyae strain P4 & $1000 \mathrm{mg} \mathrm{L}^{-1}$ in $24 \mathrm{~h}$ & (Mahajan et al. 2019) \\
Rhodococcus sp. JDC-11 & $900 \mathrm{mg} \mathrm{L}^{-1}$ in $24 \mathrm{~h}$ & (Jin et al. 2010) \\
Delftia sp. TBKNP-05 & $2780 \mathrm{mg} \mathrm{L}^{-1}$ in $120 \mathrm{~h}$ & (Patil et al. 2006) \\
Pseudomonas sp. YJB6 & $1600 \mathrm{mg} \mathrm{L}^{-1}$ in $120 \mathrm{~h}$ & (Feng et al. 2021) \\
Gordonia sp. QH-11 & $750 \mathrm{mg} \mathrm{L}^{-1}$ in $45 \mathrm{ha}$ & (Jin et al. 2012) \\
Gordonia sp. & $400 \mathrm{mg} \mathrm{L}^{-1}$ in $30 \mathrm{~h}$ & (Wu et al. 2011a) \\
Arthrobacter sp. strain ZH2 & $500 \mathrm{mg} \mathrm{L}^{-1}$ in $48 \mathrm{~h}$ & (Wang et al. 2012) \\
Methylobacillus sp. V29b & $1400 \mathrm{mg} \mathrm{L}^{-1}$ in $192 \mathrm{~h}^{\mathrm{b}}$ & (Kumar and Maitra 2016) \\
Ochrobactrum sp. JDC-41 & $500 \mathrm{mg} \mathrm{L}^{-1}$ in $72 \mathrm{~h}$ & (Wu et al. 2010) \\
Acinetobacter sp. strain LMB-5 & $400 \mathrm{mg} \mathrm{L}^{-1}$ in $60 \mathrm{~h}$ & (Fang et al. 2017) \\
Pseudomonas sp. V21b & $1200 \mathrm{mg} \mathrm{L}^{-1}$ in $192 \mathrm{~h}^{\mathrm{b}}$ & (Kumar et al. 2017) \\
Comamonas sp. 51F & $900 \mathrm{mg} \mathrm{L}^{-1}$ in $192 \mathrm{~h}^{\mathrm{b}}$ &
\end{tabular}

Strains that degrade DBP at concentrations $\geq 1000 \mathrm{mg} \mathrm{mL}^{-1}$ are further discussed in the text

${ }^{\mathrm{a}}$ With lag phase

${ }^{\mathrm{b}} \mathrm{Of} 2000 \mathrm{mg} \mathrm{L}^{-1}$ initial concentration

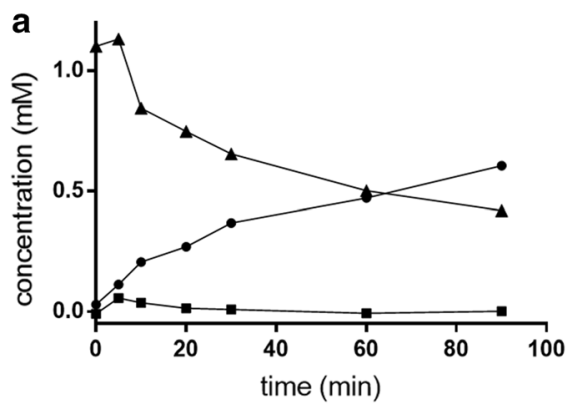

Fig. 5 In vitro esterase assay with $\mathrm{DBP}$ and MBP as substrates. a Consumption of $\operatorname{DBP}(\boldsymbol{\Delta})$, and the formation of $\operatorname{MBP}(\boldsymbol{\square})$ and PA (-) in cell extracts of Paenarthrobacter strain Shss. b Degradation of MBP ( $\square)$ and formation of PA (O) in cell

accumulation of MBP in the culture medium suggests that DBP esterase may be attached to the outer leaflet of the cytoplasmic membrane.

The sequential hydrolysis of PAEs via monoalkylated intermediates as shown for Paenarthrobacter strain Shss has been described for other PAE-degrading organisms (Akita et al. 2001; Maruyama et al. 2005; Lu et al. 2009), and cellular esterases specific for monoalkylated PAEs have been reported (Nishioka et al. 2006; Hara et al. 2010; Huang et al. 2019). Though PAE esterases have been reported to have a

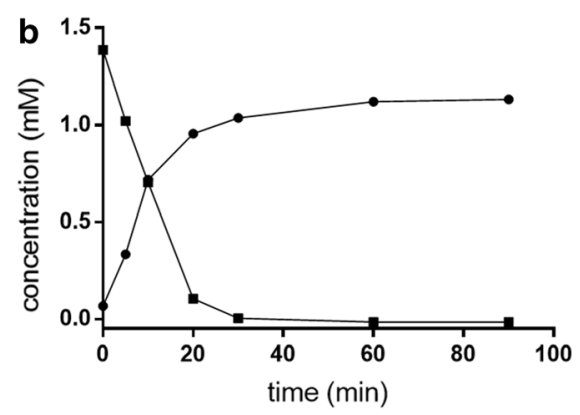

extracts. Background PA concentrations present in cell extracts without addition of DBP (a) or MBP (b) were subtracted from the values determined

cellular location, little is known about their subcellular location, and it is unknown whether PAE esterases are associated with the cytoplasmic membrane. Clear evidence for extracellular esterases involved in PAE degradation is lacking.

\section{Conclusion}

In this work the previously unknown capacity of the genus Paenarthrobacter for the degradation of PAEs 
was identified in an isolate from a highly PAEcontaminated Iranian landfill. It proceeds via the stepwise hydrolysis of the two ester bonds by two highly active cellular esterases followed by the consumption of the PA formed. The esterases are highly efficient as the growth rate with DBP and PA was similar suggesting that complete degradation of PA rather than the conversion DBP to PA appears to be rate-limiting.

The degradation capacity of Paenarthrobacter strain Ssh is amongst the fastest reported so far. Consequently, we propose that Paenarthrobacter strain Shss plays a previously overseen important role in the elimination of DBP from contaminated soil. Due to its rapid growth and high degradation capacities it might serve as a promising candidate strain for PAE degradion in engineered systems.

Acknowledgements This work was funded by German research council, Fund Number BO 1565/16-2. The TEM (Hitachi HT7800) was funded by the DFG grant (Project Number 426849454) and is operated by the University of Freiburg, Faculty of Biology, as a partner unit within the Microscopy and Image Analysis Platform (MIAP) and the Life Imaging Center (LIC), Freiburg.

Funding Open Access funding enabled and organized by Projekt DEAL.

Open Access This article is licensed under a Creative Commons Attribution 4.0 International License, which permits use, sharing, adaptation, distribution and reproduction in any medium or format, as long as you give appropriate credit to the original author(s) and the source, provide a link to the Creative Commons licence, and indicate if changes were made. The images or other third party material in this article are included in the article's Creative Commons licence, unless indicated otherwise in a credit line to the material. If material is not included in the article's Creative Commons licence and your intended use is not permitted by statutory regulation or exceeds the permitted use, you will need to obtain permission directly from the copyright holder. To view a copy of this licence, visit http://creativecommons.org/licenses/by/4.0/.

\section{References}

Akita K, Naitou C, Maruyama K (2001) Purification and characterization of an esterase from Micrococcus sp. YGJ1 hydrolyzing phthalate esters. Biosci Biotechnol Biochem 65:1680-1683. https://doi.org/10.1271/bbb.65.1680

Baloyi ND, Tekere M, Maphangwa KW, Masindi V (2021) Insights into the prevalence and impacts of phthalate esters in aquatic ecosystems. Front Environ Sci. https://doi.org/ 10.3389/FENVS.2021.684190

Benjamin S, Kamimura N, Takahashi K, Masai E (2016) Achromobacter denitrificans SP1 efficiently utilizes 16 phthalate diesters and their downstream products through protocatechuate 3,4-cleavage pathway. Ecotoxicol Environ Saf 134:172-178. https://doi.org/10.1016/j.ecoenv.2016. 08.028

Boll M, Geiger R, Junghare M, Schink B (2020) Microbial degradation of phthalates: biochemistry and environmental implications. Environ Microbiol Rep 12:3-15. https://doi. org/10.1111/1758-2229.12787

Chowdhary P, Raj A, Bharagava RN (2018) Environmental pollution and health hazards from distillery wastewater and treatment approaches to combat the environmental threats: a review. Chemosphere 194:229-246

Ebenau-Jehle C, Mergelsberg M, Fischer S et al (2017) An unusual strategy for the anoxic biodegradation of phthalate. ISME J 11:224-236. https://doi.org/10.1038/ismej.2016. 91

Fang Y, Zhang L, Wang J et al (2017) Biodegradation of phthalate esters by a newly isolated Acinetobacter sp. strain LMB-5 and characteristics of its esterase. Pedosphere 27:606-615. https://doi.org/10.1016/S10020160(17)60355-2

Feng NX, Feng YX, Liang QF et al (2021) Complete biodegradation of di-n-butyl phthalate (DBP) by a novel Pseudomonas sp. YJB6. Sci Total Environ 761:143208. https://doi.org/10.1016/j.scitotenv.2020.143208

Gao DW, Wen ZD (2016) Phthalate esters in the environment: a critical review of their occurrence, biodegradation, and removal during wastewater treatment processes. Sci Total Environ 541:986-1001. https://doi.org/10.1016/j. scitotenv.2015.09.148

Gao D, Li Z, Wang H, Liang H (2018) An overview of phthalate acid ester pollution in China over the last decade: environmental occurrence and human exposure. Sci Total Environ 645:1400-1409. https://doi.org/10.1016/j. scitotenv.2018.07.093

Hara H, Stewart GR, Mohn WW (2010) Involvement of a novel $\mathrm{ABC}$ transporter and monoalkyl phthalate ester hydrolase in phthalate ester catabolism by Rhodococcus jostii RHA1. Appl Environ Microbiol 76:1516-1523. https://doi.org/10. 1128/AEM.02621-09

Huang YH, Huang XJ, Chen XH et al (2018) Biodegradation of di-butyl phthalate (DBP) by a novel endophytic bacterium Bacillus subtilis and its bioaugmentation for removing DBP from vegetation slurry. J Environ Manag 224:1-9. https://doi.org/10.1016/j.jenvman.2018.07.023

Huang H, Zhang XY, Chen TL et al (2019) Biodegradation of structurally diverse phthalate esters by a newly identified esterase with catalytic activity toward di(2-ethylhexyl) phthalate. J Agric Food Chem 67:8548-8558. https://doi. org/10.1021/acs.jafc.9b02655

Jin DC, Liang RX, Dai QY et al (2010) Biodegradation of di-nbutyl phthalate by Rhodococcus sp. JDC-11 and molecular detection of 3,4-phthalate dioxygenase gene. J Microbiol Biotechnol 20:1440-1445. https://doi.org/10.4014/jmb. 1004.04034

Jin D, Bai Z, Chang D et al (2012) Biodegradation of di-n-butyl phthalate by an isolated Gordonia sp. strain QH-11: genetic 
identification and degradation kinetics. J Hazard Mater 221-222:80-85. https://doi.org/10.1016/j.jhazmat.2012. 04.010

Jin D, Kong X, Li Y et al (2015) Biodegradation of di-n-butyl phthalate by Achromobacter sp. isolated from rural domestic wastewater. Int $\mathrm{J}$ Environ Res Public Health 12:13510-13522. https://doi.org/10.3390/ ijerph121013510

Kahn LG, Philippat C, Nakayama SF et al (2020) Endocrinedisrupting chemicals: implications for human health. Lancet Diabetes Endocrinol 8:703-718. https://doi.org/10. 1016/S2213-8587(20)30129-7

Karimpour-Fard M (2019) Rehabilitation of Saravan dumpsite in Rasht, Iran: geotechnical characterization of municipal solid waste. Int J Environ Sci Technol 16:4419-4436. https://doi.org/10.1007/s13762-018-1847-z

Kumar V, Maitra SS (2016) Biodegradation of endocrine disruptor dibutyl phthalate (DBP) by a newly isolated Methylobacillus sp. V29b and the DBP degradation pathway. 3 Biotech 6:1-12. https://doi.org/10.1007/s13205016-0524-5

Kumar V, Sharma N, Maitra SS (2017) Comparative study on the degradation of dibutyl phthalate by two newly isolated Pseudomonas sp. V21b and Comamonas sp. 51F. Biotechnol Rep 15:1-10. https://doi.org/10.1016/j.btre. 2017.04.002

Liang DW, Zhang T, Fang HHP, He J (2008) Phthalates biodegradation in the environment. Appl Microbiol Biotechnol 80:183-198

Lu Y, Tang F, Wang Y et al (2009) Biodegradation of dimethyl phthalate, diethyl phthalate and di-n-butyl phthalate by Rhodococcus sp. L4 isolated from activated sludge. J Hazard Mater 168:938-943. https://doi.org/10.1016/j. jhazmat.2009.02.126

Mahajan R, Verma S, Kushwaha M et al (2019) Biodegradation of di-n-butyl phthalate by psychrotolerant Sphingobium yanoikuyae strain $\mathrm{P} 4$ and protein structural analysis of carboxylesterase involved in the pathway. Int $\mathrm{J}$ Biol Macromol 122:806-816. https://doi.org/10.1016/j. ijbiomac.2018.10.225

Maruyama K, Akita K, Naitou C et al (2005) Purification and characterization of an esterase hydrolyzing monoalkyl phthalates from Micrococcus sp. YGJ1. J Biochem 137:27-32. https://doi.org/10.1093/jb/mvi004

Net S, Sempéré R, Delmont A et al (2015) Occurrence, fate, behavior and ecotoxicological state of phthalates in different environmental matrices. Environ Sci Technol 49:4019-4035

Niazi JH, Prasad DT, Karegoudar TB (2001) Initial degradation of dimethylphthalate by esterases from Bacillus species. FEMS Microbiol Lett 196:201-205. https://doi.org/10. 1111/j.1574-6968.2001.tb10565.x

Nishioka T, Iwata M, Imaoka T et al (2006) A mono-2-ethylhexyl phthalate hydrolase from a Gordonia sp. that is able to dissimilate di-2-ethylhexyl phthalate. Appl Environ Microbiol 72:2394-2399. https://doi.org/10.1128/AEM. 72.4.2394-2399.2006

Oehlmann J, Schulte-Oehlmann U, Kloas W et al (2009) A critical analysis of the biological impacts of plasticizers on wildlife. Philos Trans R Soc B 364:2047-2062
Patil NK, Kundapur R, Shouche YS, Karegoudar TB (2006) Degradation of a plasticizer, di-n-butylphthalate by Delftia sp. TBKNP-05. Curr Microbiol 52:225-230. https://doi. org/10.1007/s00284-005-0258-9

Shariatmadari N, Askari Lasaki B, Eshghinezhad H, Alidoust P (2018) Effects of landfill leachate on mechanical behaviour of adjacent soil: a case study of Saravan landfill, Rasht, Iran. Int J Civ Eng 16:1503-1513. https://doi.org/10.1007/ s40999-018-0311-2

Sungkeeree P, Whangsuk W, Dubbs J et al (2016) Biodegradation of endocrine disrupting dibutyl phthalate by a bacterial consortium expressing Sphingobium sp. SM42 esterase. Process Biochem 51:1040-1045. https://doi.org/ 10.1016/j.procbio.2016.04.014

Wang Y, Miao B, Hou D et al (2012) Biodegradation of di-nbutyl phthalate and expression of the 3,4-phthalate dioxygenase gene in Arthrobacter sp. ZH 2 strain. Process Biochem 47:936-940. https://doi.org/10.1016/j.procbio. 2012.02.027

Wu XL, Wang YY, Liang RX et al (2010) Degradation of di-nbutyl phthalate by newly isolated Ochrobactrum sp. Bull Environ Contam Toxicol 85:235-237. https://doi.org/10. 1007/s00128-010-0080-3

Wu X, Wang Y, Dai Q et al (2011a) Isolation and characterization of four di-n-butyl phthalate (DBP)-degrading Gordonia sp. strains and cloning the 3,4-phthalate dioxygenase gene. World J Microbiol Biotechnol 27:2611-2617. https:// doi.org/10.1007/s11274-011-0734-2

Wu X, Wang Y, Liang R et al (2011b) Biodegradation of an endocrine-disrupting chemical di-n-butyl phthalate by newly isolated Agrobacterium sp. and the biochemical pathway. Process Biochem 46:1090-1094. https://doi.org/ 10.1016/j.procbio.2011.01.031

$\mathrm{Xu}$ XR, Bin LH, Gu JD (2005) Biodegradation of an endocrinedisrupting chemical di-n-butyl phthalate ester by Pseudomonas fluorescens B-1. Int Biodeterior Biodegrad 55:9-15. https://doi.org/10.1016/j.ibiod.2004.05.005

Xu Y, Minhazul K, Wang X et al (2020) Biodegradation of phthalate esters by Paracoccus kondratievae BJQ0001 isolated from Jiuqu (Baijiu fermentation starter) and identification of the ester bond hydrolysis enzyme. Environ Pollut 263:114506. https://doi.org/10.1016/j.envpol.2020. 114506

Yuan L, Cheng J, Chu Q et al (2019) Di-n-butyl phthalate degrading endophytic bacterium Bacillus amyloliquefaciens subsp. strain JR20 isolated from garlic chive and its colonization in a leafy vegetable. J Environ Sci Health B 54:693-701. https://doi.org/10.1080/03601234.2019. 1633211

Zhao HM, Du H, Feng NX et al (2016) Biodegradation of di-nbutylphthalate and phthalic acid by a novel Providencia sp. $2 \mathrm{D}$ and its stimulation in a compost-amended soil. Biol Fertil Soils 52:65-76. https://doi.org/10.1007/s00374-0151054-8

Publisher's Note Springer Nature remains neutral with regard to jurisdictional claims in published maps and institutional affiliations. 